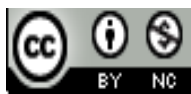 \\ Jurnal Terapan Manajemen dan Bisnis is licensed under
}

A Creative Commons Attribution-NonCommercial 4.0 International License.

\title{
IMPLEMENTATION OF LOCAL TAX SERVICE POLICIES AT THE REGIONAL TAX AND RETRIBUTION MANAGEMENT AGENCY OFFICE OF PALANGKA RAYA CITY
}

\author{
T Kristiana1), RI Poetri2) \\ 1) Kristen University Palangka Raya, Palangka Raya, Indonesia \\ E-mail: tresiakristiana@yahoo.co.id \\ 2) Palangka Raya University, Palangka Raya, Indonesia \\ E-mail: reinypoetri89@gmail.com
}

\begin{abstract}
Law Number 28 of 2009 concerning Regional Taxes and Regional Levies, is the basis for implementing tax collection. The authority to impose local taxes and levies collected from the public is used to pay for services provided to the community. The potential for collecting local taxes and levies as one of the components of regional original revenue (PAD) revenue. PAD is regional revenue originating from resources within the region itself, used to finance development. Therefore, the role of local taxes and levies as one of the elements of regional original income must be optimized in their collection according to the prevailing laws and regulations.

The Regional Tax and Retribution Management Agency Office of Palangka Raya City is one of the agencies that manage local taxes. Basically, the tendency of the regions to create various levies that are not in accordance with the provisions of laws and regulations and that are against the public interest can be overcome by the government by supervising each regional regulation that regulates such taxes and levies. Based on the foregoing, this study aims to describe the quality of tax services at the Regional Tax and Retribution Management Agency Office of Palangka Raya City and to describe the tax service process in increasing the realization of the target achievement of Regional Taxes and Levies at the Regional Tax and Retribution Management Agency Office of Palangka Raya City.

The research method used in this research is an exploratory research method with an inductive approach. The author goes to the field to look for facts where the object to be studied is located. Researchers describe the problems that occur in the field in general, accompanied by facts and data so that the description of the existing problems becomes valid and deserves a solution. Data collection methods with in-depth interviews, observation, and documentation study. Research informants are all office employees regional Tax and Retribution Management Agency for Palangka Raya City and some tax and retribution payers in Palangkaraya City. Data analysis was performed by data reduction, data presentation, and concluding.

The results of research by the Regional Tax and Retribution Management Agency (BPPRD) of Palangka Raya city were formed in 2016 based on Regional Regulation (Perda) No. 11 of 2016, the Palangka Raya City BPRD Office according to the provisions manages 9 types of local taxes consisting of Hotel Tax, Restaurant Tax, Entertainment Tax, Parking Tax,
\end{abstract}


Groundwater Tax, Swallow's Nest Tax, Non-Metal Mineral, and Rock Tax, Taxes Rural and Urban Land and Buildings, Fees for Land and Buildings. In providing services to taxpayers, the Office of the Regional Tax and Retribution Management Agency for the City of Palangka Raya implements tangible service standards, reliability, responsiveness, assurance, empathy. Achievement of targets and realization averaged over $80 \%$ of the provisions for Regional Taxes and Charges.

Keywords: Service; Tax; Management

\section{Introduction}

The government should serve the community (Public Servant) in various aspects of the interests of social life. Local government as an autonomous region is given the rights and obligations to regulate the region according to its potential. As stated in Law Number 28 of 2009 concerning Regional Taxes and Regional Levies, that in the framework of implementing regional government, each region has the right and obligation to regulate and manage its government affairs to increase the efficiency and effectiveness of government administration and services to the community.

The authority to collect Regional Taxes and Retribution (PDRD) to the community, the results will be used to pay for services provided to the community. This is an important element in a government system that adheres to the principle of decentralization. Various kinds of problems and obstacles faced in the collection of local taxes and levies ranging from regulations to the implementation of PDRD collection. The most basic criteria for PDRD collection is so that PDRD collected from the community can provide the greatest possible welfare and benefits for the entire community.

The potential for collecting local taxes and levies as one of the components of regional original revenue (PAD) revenue. Regional autonomy is said to be successful if regions are able to finance their regions. And PAD is regional income that comes from resources within the region itself. One source of regional income is to finance development. Therefore, the role of regional taxes and levies as one of the elements of regional original income needs to be optimized in their collection according to the prevailing laws and regulations.

Apart from the government's policy by linking the tax paid off the instrument to the current year, public awareness in paying taxes also greatly depends on the quality of services provided by employees. In the concept of service quality expressed by Kotler (2018), there are 5 elements, namely:

a. Tangible is the physical aspect of service and includes the appearance of physical facilities, equipment, personnel, and communication materials, because the service itself is intangible, consumers often judge the quality of service from tangible things related to service.

b. Reliability in service is defined differently and reliability in products. In services, reliability is related to the ability to perform the promised services reliably and accurately.

c. Responsiveness is the desire of service providers to help consumers and provide responsive and fast services.

d. Assurance relates to the knowledge and goodness of workers and their ability to convey trust and confidence.

e. Empathy (empathy) is the ability to show individual concern for consumers

If the concept of service quality is implemented properly by employees in providing services, the implementation of policies on regional taxes and levies that have 
been stipulated in the legislation will be achieved according to the objectives. The Regional Tax and Retribution Management Agency Office of Palangka Raya City is one of the agencies that manage local taxes. Basically, the tendency of the regions to create various levies that are not in accordance with the provisions of laws and regulations and that are against the public interest can be overcome by the government by supervising each regional regulation that regulates such taxes and levies The law gives the Government the authority to cancel any Regional Regulations that contradict the Law and the public interest.

Regional Regulations that regulate taxes and levies within 15 (fifteen) working days from stipulation must be submitted to the Government. Within 30 (thirty) working days the Government can cancel the Regional Regulations that regulate taxes and levies. In reality, the supervision of these Regional Regulations cannot run effectively. Many Regions do not submit Regional Regulations to the Government and some Regions still enforce Regional Regulations that have been canceled by the Government.

The supervision is ineffective because the existing law does not regulate sanctions against regions that violate these provisions and the supervisory system is repressive. Regional Regulations can be directly implemented by Regions without prior approval from the Government. The current regulation of taxation and levies authority does not support the implementation of regional autonomy.

The granting of greater authority to regions in administering governance and services to the community should also be followed by granting greater authority in taxation and levies. District and city tax bases are very limited and the absence of provincial authority in determining their tax rates has resulted in regions experiencing difficulties in meeting their expenditure needs.

The phenomenon that often occurs in local government agencies is the Standardization of Regional Tax Services and Regional Retributions, which are expected to be a reference for Regional Governments in implementing local tax and levies in accordance with applicable laws and regulations so that they can be more optimal in providing services to the community, especially the Obligators. Tax. To collect local taxes and levies requires supporting components, namely adequate facilities and infrastructure. The adequate facilities and infrastructure aim to make the collection of local taxes and levies more optimally.

Based on the existing phenomena and facts, the problems in this study are:

1. How is the service quality at the Regional Tax and Retribution Management Agency Office of Palangka Raya City?

2. How is the service process in increasing the realization of the target achievement of Regional Taxes and Levies at the Regional Tax and Retribution Management Agency Office of Palangka Raya City?

\section{Literature Review}

Service Quality

Quality of service is one of the keys to the success of any business. This quality of service is provided to consumers to meet consumer expectations by providing products and services at an acceptable price level and creating "value" for consumers and generating profit for the company. Each industry segment has a term for consumers. Hotels call them guests, banks call them customers, airlines call them passengers, travel agents call them clients. If in tax collection activities, it is known as taxpayers, and this is clarified in the laws and regulations on taxes, both central government taxes, and local government regulations.

Service quality is always related to service. Services are activities, benefits, or satisfaction in the form of services offered by institutions as producers to be sold to 
consumers. For example repair workshops, beauty salons, skills courses, hotels, hospitals, schools, and so on.

According to Moekijat (2019), Service is services, services. Services in marketing management are activities, conditions, or satisfactions given for sale, for example, haircuts, repairs. According to Kotler (2018), service is any action or activity offered by one party to another, which is basically intangible and acts result in any ownership, production can be linked or cannot be associated with a physical product.

According to Swastha (2018), services are intangible products that are bought and sold in the market through a mutually satisfying exchange transaction, if goods are produced, then services are carried out. Thus, the quality of a subtle product (service) is derived from its performance or performance, not from its physical characteristics. According to Ahyari (2015), the results of production activities do not have a certain form, do not have certain physical and chemical properties, and there is no time between the production and use processes.

According to Wyckof (Lovelock, 1988; Tjiptono, 2017), service quality is the level of excellence expected and control over that level of excellence to meet customer desires. According to Kotler, (2018); a good quality image is not based on the point of view or perception of the service provider, but based on the point of view or perception of the customer.

Meanwhile, principles of public service according to the Decree of MENPAN Number 25 of 2004, where the concept of service standards and service principles are translated into 14 elements that are "relevant, valid and reliable", as the minimum elements that must be present for measuring the community satisfaction index are as follows:

a. Service Procedure, namely the ease of service stages provided to the community in terms of simplicity of service flow.

b. Service Requirements, namely the technical and administrative requirements needed to obtain service according to the type of service.

c. Clarity of Service Officers, namely the seriousness of officers in providing services (name, position, authority, and responsibility).

d. Service officer discipline, namely the seriousness of the officer in providing services, especially the consistency of working time in accordance with applicable regulations.

e. Responsibilities of service officers, namely clarity of authorities and responsibilities of officers in providing and completing services.

f. The ability of service officers, namely the level of expertise and skills possessed by officers in providing/completing services to the community.

g. Service speed, namely the target time for the service to be completed within the time determined by the service provider unit.

h. Justice gets service, namely the implementation of services without differentiating the class/status of the community being served.

i. Courtesy and friendliness of officers, namely the attitude and behavior of officers in giving to the community in a polite and friendly manner as well as mutual respect and respect.

j. Fairness of service costs, namely the affordability of the community to the costs set by the service unit.

k. Service fee certainty, namely the match between the fees paid and the fees that have been determined.

1. Service schedule certainty, namely the implementation of service time, in accordance with the stipulated provisions. 
m. Environmental comfort, namely the condition of service facilities and infrastructure that is clean, neat, and orderly to provide a sense of comfort to service recipients.

$\mathrm{n}$. Service security, namely the assurance of the environmental security level of the service provider unit or the facilities used, so that the community feels calm about getting services against the risks resulting from the implementation of the service.

\section{Research Methods}

The research method used in this research is an exploratory research method with an inductive approach. The writer goes to the field to find the facts about the object to be studied. Researchers describe the problems that occur in the field in general, accompanied by facts and data so that the description of the existing problems becomes valid and deserves a solution.

Data collection methods with in-depth interviews, observation, and documentation study. Research informants are all office employees Regional Tax and Retribution Management Agency for Palangka Raya City and some tax and retribution payers in Palangkaraya City. Data analysis was performed by data reduction, data presentation, and concluding.

\section{Results and Discussion}

The Regional Tax and Retribution Management Agency (BPPRD) of Palangka Raya City was formed in 2016 based on Regional Regulation (Perda) No. 11 of 2016. This agency carries out service activities for collecting local taxes and levies in the City of Palangka Raya. The organizational body of the Regional Tax and Retribution Management Agency (BPPRD) of Palangka Raya city can be seen in Appendix 4 with the organizational structure and its sub-sub-sections 1.

Table 1 Leaders and Heads of Fields, Sub-Sectors, and the Head of Division

\begin{tabular}{clcc} 
No. & \multicolumn{1}{c}{ Job Description } & Number of People & $\%$ \\
\hline 1. & Head of Agency & 1 & 4.76 \\
2. & Secretary & 1 & 4.76 \\
3. & Head of Division & 4 & 19.05 \\
4. & Head of subdivision & 12 & 57.14 \\
5. & Head of the subsection & 3 & 14.29 \\
\hline & $\quad$ Total & $\mathbf{2 1}$ & $\mathbf{1 0 0 . 0 0}$ \\
\hline
\end{tabular}

Source: Office of the Regional Tax and Retribution Management Agency, Palangka Raya City

At the Office of the Regional Tax and Retribution Management Agency of the City of Palang Raya, there is the honorary staff who help the operational activities of the Regional Tax and Retribution Management Agency of Palangka Raya City, with their respective fields of work. The honorary staff can be seen in Table 2 .

Table 2 Honorary Employees

\begin{tabular}{ccccc}
\hline No. & & Gender & Number of People & $\%$ \\
\hline 1. & Men & & 34 & 56.67 \\
2. & Woman & & 26 & 43.33 \\
\hline & & Total & $\mathbf{6 0}$ & $\mathbf{1 0 0 . 0 0}$ \\
\hline
\end{tabular}

Source: Office of the Regional Tax and Retribution Management Agency, Palangka Raya City 
In addition to the honorary work plan (contra), there are also civil servants (PNS) at the Regional Tax and Retribution Management Agency for Palangka Raya City, as in Table 3 based on gender.

Table 3 Civil Civil Servants

\begin{tabular}{clccc}
\hline No. & & Gender & Number of People & $\%$ \\
\hline 1. & Men & & 28 & 48.28 \\
2. & Woman & & 30 & 51.72 \\
\hline & & Total & $\mathbf{5 8}$ & $\mathbf{1 0 0 . 0 0}$ \\
\hline
\end{tabular}

Source: Office of the Regional Tax and Retribution Management Agency, Palangka Raya City

The Regional Tax and Retribution Management Agency Office of Palangka Raya City collects taxes consisting of 9 (nine) types of Regional taxes managed by the Palangka Raya City Tax Management and Retribution Agency in accordance with Regional Regulation Number 4 of 2018 concerning Regional Taxes among others:

a. Hotel Tax

Hotel tax is a tax on services provided by hotels including guest houses, lodgings, boarding houses/barracks starting from 10 doors with the amount of the Kost/Wisma Tax Imposition Rate is 5\% and 10\% Imposition Rate for Hotel Tax and the number of payments received/that should be paid to the Hotel.

b. Restaurant Tax

Restaurant tax is a service level tax provided by restaurants including restaurants, stalls, catering, cafes, canteens, and bars with a 5\% tax rate with an income of more than Tp. 200,000 to Rp. 500,000 per day and 10\% of sales revenue for restaurants with an income of more than Rp. 500,000 per day.

c. Entertainment Tax

Entertainment tax is a tax collected on the organization of entertainment. The entertainment services that are collected are Movie/Cinema, Art Management, Dsychotic, Karaoke, Billiard Games, Motorized Race, Skill Games, Massage/Reflexology, Steam Bath/Spa, Fitness/Fitness Center, Swimming Pool/Fishing Pool, and Futsal Field.

The amount of the Tax Imposition Rate for Entertainment Tax is divided into several types:

- $10 \%$ for Movie/Cinema Watch

- $10 \%$ for traditional art performances. For example, dance and clothing

- $10 \%$ for Beauty and Body Building Contests

- $25 \%$ for Discotheque, Karaoke, Club Malan

- $10 \%$ for Circus, Acrobatics, and Magic

- $10 \%$ for Billiards and Bowling

- $10 \%$ for Horse Racing, Motorbikes, Agility Games

- $20 \%$ for Massage, Reflexology, Steam Bath/Spa, Fitness Center, and

- $10 \%$ for Sports Match.

d. Parking Tax

Parking tax is a tax on the operation of parking spaces outside of road entities, whether provided in connection with the main business or provided as a business, including the provision of storage for motorized vehicles. The amount of the tax imposition rate is $20 \%$ of the total payment or which should be paid to the parking lot management. 
e. Groundwater Tax (ABT)

Groundwater Tax (ABT) is a tax on the activities of extracting and utilizing groundwater used by individuals or entities with a tax rate of $20 \%$ of the acquired value of groundwater.

f. Swallow's Nest Tax

Swallow's Nest Tax is a tax on the activity of taking swallow's nests because the tax on Swallow's Nests is $10 \%$.

g. Tax Non-Metal Minerals and Rocks (Minerba)

Tax on Non-Metal Minerals and Rocks (Minerba) is a tax on the activities of extracting, utilizing, processing, and refining non-metal minerals and rocks, both from natural sources in and or the surface of the earth for use, with the imposition of taxes that are divided into two, that is:

- Traditional miners are subject to a tax of $10 \%$ and

- For entrepreneurs, the taxable rate is $25 \%$.

h. Rural and Urban Land and Building Tax (PBB P2)

Rural and urban land and building taxes are lands and/or buildings that are owned, controlled, and/or utilized by private persons or entities. With the Tax Object Selling Value (NJOP) greater than or equal to Rp. 1,000,000,000 is determined at $0.2 \%$ and the Tax Object Selling Value (NJOP) is less than Rp. 1,000,000,000 is determined at $0.1 \%$

i. Acquisition Fee on Land and Building (BPHTB)

Fees for the acquisition of land and building rights (PBHTB) are levies on the processing of rights to land and buildings. Acquisition of rights over land and/or building is a legal act or event that results in the acquisition of rights to and/or buildings by an individual or entity with an amount of $5 \%$ tax.

To provide the best service to the Regional Taxpayers and Retribution, the Office of the Regional Tax and Retribution Management Agency for Palangka Raya City implements service standards in accordance with the provisions of the law. The policy carried out by the Office of the Regional Tax and Retribution Management Agency of Palangka Raya City in optimizing tax collection has carried out two tax payment mechanisms, namely the Online and Offline Payment mechanism (through the Receiving Treasurer).

Other policies set by the Agency Office The Regional Tax and Retribution Management Agency for the City of Palangka Raya to optimize the results of tax collection is to carry out activities including:

a. Crossing Fair

It is an annual routine activity where this activity is the Palangka Raya City Anniversary event which is attended by all SKPDs in the city of Palangka Raya. The Regional Tax Management Agency gets a stand where it will carry out tax receipts and consultations, in which this activity if the taxpayer makes payments at the STAND will get a Lottery Coupon which will be drawn at the peak of the event. Where the prizes offered to taxpayers are not small gifts, there are bicycles, refrigerators, dispensers, TVs, gas stoves, and other prizes. Not only taxpayers who get prizes, but SKPD stands are required to beautify the stands as attractive as possible to become the best booths. The Regional Tax Management Agency itself has won the winner with the second-best stand (2) for the last two years.

b. Taxpayer Findings

Activities that provide material, explain, and socialize about taxes managed by the Regional Tax and Retribution Management Agency such as Regional Taxes, PBB-P2, and 
BPHTB. In 2019, the Regional Tax and Retribution Management Agency has organized the Socialization of Regional Tax Regulations on Taxes and Charges, where the Management Body can coordinate to hear complaints about tax authorities about the taxes they manage from regulations, tax calculations to inputs for the Tax Management Agency. and Regional Retribution for Palangka Raya City. In the Socialization of Regional Tax Regulations regarding taxes and levies, the Management Body also provides rewards to taxpayers who are consistent in paying taxes without being subject to fines.

c. Conscious Movement of Tax Payment (GSM)

Is an annual routine activity that is carried out at the end of the year or before the tax period ends. This activity is the peak activity in which it receives reception at a place (BRI, POS Office, and Locket BPPRD) and a lot of entertainment to door price. The TaxPaying Awareness Movement (GSM) always provides convenience services for Tax Wajin such as folk entertainment, singing together, snacks, free reflections to the existence of the UKM Stand by Anak Palangka Raya.

The Tax Conscious Movement is carried out in 3 hearts where the highlight of the show will share the Wow Door Price with motorbikes, bicycles, TVs, refrigerators, dispensers, cellphones, and other attractive prizes.

As for the results of target achievement and realization of tax collection policies carried out according to standards and maximum attainment efforts, the data can be seen in Table 4 .

Table 4 Tax Target and Realization for 2019

\begin{tabular}{|c|c|c|c|}
\hline \multirow{2}{*}{ Description } & \multicolumn{3}{|c|}{ The 2019 Year } \\
\hline & Target & Realization & $(\%)$ \\
\hline Hotel Tax & $11,000,000,000.00$ & $7,725,142,968.84$ & 70.23 \\
\hline Restaurant tax & $14,100,000,000.00$ & $13,654,469,908.00$ & 96.84 \\
\hline Entertainment Tax & $3,200,000,000.00$ & $2,800,106,392.00$ & 87.50 \\
\hline Advertisement tax & $1,330,000,000.00$ & $784,265,441.00$ & 65.73 \\
\hline Public Street Lighting Tax & $33,000,000,000.00$ & $28,956,948,065.00$ & 87.75 \\
\hline Parking Tax & $590,000,000.00$ & $548,301,467.00$ & 92.93 \\
\hline Groundwater Tax & $77,000,000.00$ & $80,051,212.00$ & 103.96 \\
\hline Swallow's Nest Tax & $120,000,000.00$ & $106,811,800.00$ & 89.01 \\
\hline $\begin{array}{l}\text { Non-Metal Mineral and } \\
\text { Rock Tax }\end{array}$ & $1,845,000,000.00$ & $1,830,459,110.00$ & 99.21 \\
\hline $\begin{array}{l}\text { Rural and Urban Land and } \\
\text { Building Tax }\end{array}$ & $13,620,450,559.00$ & $11,952,223,367.00$ & 87.75 \\
\hline $\begin{array}{l}\text { Fees for Acquisition of } \\
\text { Rights to Land and } \\
\text { Buildings }\end{array}$ & $21,200,000,000.00$ & $17,562,318,722.00$ & 82.84 \\
\hline Total & & $57,044,150,387.84$ & \\
\hline
\end{tabular}

Source: Regional Tax and Retribution Management Agency of Palangka Raya City

\section{Conclusion}

Based on the results of research and data analysis, it can be concluded that the quality of services for collecting local taxes and levies at the Regional Tax and Retribution Management Agency Office of Palangka Raya City is carried out concerning the provisions of service standard quality, reliability, responsiveness, assurance, empathy. Achievement of 
targets and realization averaged over $80 \%$ of the provisions for regional taxes and levies. Policies undertaken to optimize the results of tax collection include carrying out activities including the Palangka Raya fair, taxpayer meetings, and the Conscious Movement to pay taxes.

To provide or improve the quality of service to the taxpayer community, besides the morale of the serving employees, it is necessary to improve such as reliability, the ability to perform the promised service reliably and accurately, responsiveness to help consumers, and provide responsive services. and fast, assurance (assurance) is related to knowledge and ability to convey trust and belief, and empathy (empathy), namely the ability to show individual concern for consumers, and tangible is the physical aspect of a service such as equipment, personnel, and materials. communication, because the service itself is intangible.

\section{References}

Ahyari, Agus. (2005). Manajemen Produksi, Perencanaan Sistem Produksi. Yogyakarta: BPFE.

Kotler, Philip. (2010). Manajemen Pemasaran: Analisis, Perencanaan, Implementasi, dan Pengendalian, Jakarta: PT. Prenhallindo.

Moekijat. (2009). Manajemen Kepegawaian. Bandung: Mandar Maju.

Moleong, L.J. (2007). Metodologi Penelitian Kualitatif. Bandung: Remaja Rosadakarya.

Sugiyono. (2009). Metode Penelitian Bisnis. Bandung: Alfabeta.

Swastha D.H., Basu. (2008). Azas-azas Marketing. Edisi Revisi. Yogyakarta: Liberty.

Tjiptono, Fandy. (2000). Strategi Bisnis Modern. Yogyakarta: Andi offset. 